\title{
THORACOLUMBAR SPINAL ARTHRODESIS - EPIDEMIOLOGY AND COSTS
}

\author{
ARTRODESE DE COLUNA TORACOLOMBAR - EPIDEMIOLOGIA E CUSTOS
}

\author{
ARTRODESIS DE LA COLUMNA TORACOLUMBAR - EPIDEMIOLOGÍA Y COSTOS

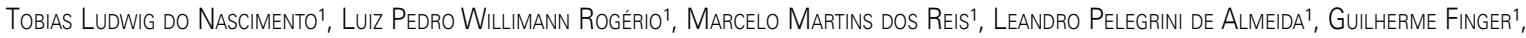 \\ Gabriel Frizon Greggianin ${ }^{1}$, Tadeu Ludwig do Nascimento², André Martins de Lima Cecchinl ${ }^{1}$, Felipe Martins de Lima CecchinI ${ }^{1}$, Ericson Sfreddo ${ }^{1}$
}

1. Hospital Cristo Redentor, Neurosurgery Service, Porto Alegre, RS, Brazil.

2. Universidade Federal do Rio Grande do Sul Medical School, Porto Alegre, RS, Brazil.

\begin{abstract}
Objective: To describe the epidemiology of patients with thoracolumbar spine fracture submitted to surgery at Hospital Cristo Redentor and the related costs. Methods: Prospective epidemiological study between July 2014 and August 2015 of patients with thoracolumbar spine fracture with indication of surgery. The variables analyzed were sex, age, cost of hospitalization, fractured levels, levels of arthrodesis, surgical site infection, UTI or BCP, spinal cord injury, etiology, length of stay, procedure time, and visual analog scale (VAS). Results: Thirty-two patients were evaluated in the study period, with a mean age of 38.68 years. Male-female ratio was 4:1 and the most frequent causes were fall from height (46.87\%) and traffic accidents (46.87\%). The thoracolumbar transition was the most affected (40.62\%), with L1 vertebra involved in $23.8 \%$ of the time. Neurological deficit was present in $40.62 \%$ of patients. Hospital stay had a median of 14 days and patients with neurological deficit were hospitalized for a longer period $(p<0.001)$, with an increase in hospital costs $(p=0.015)$. The average cost of hospitalization was $U \$ 2,874.80$. The presence of BCP increased the cost of hospitalization, and patients with spinal cord injury had more BCP $(p=0.014)$. Conclusion: Public policies with an emphasis on reducing traffic accidents and falls can help reduce the incidence of these injuries and studies focusing on hospital costs and rehabilitation need to be conducted in Brazil to determinate the burden of spinal trauma and spinal cord injury.
\end{abstract}

Keywords: Spine; Spinal fractures; Spinal injuries.

\section{RESUMO}

Objetivo: Descrever a epidemiologia dos pacientes com fratura de coluna toracolombar submetidos à cirurgia no Hospital Cristo Redentor e os custos relacionados. Métodos: Estudo epidemiológico prospectivo entre julho de 2014 e agosto de 2015 de pacientes com fratura da coluna toracolombar com indicação de cirurgia. Foram analisadas as variáveis sexo, idade, custo da internação hospitalar, níveis fraturados, níveis de artrodese, infecção de sítio cirúrgico, ITU ou BCP, lesão medular, etiologia, dias de internação, tempo de procedimento e escala visual analógica (EVA). Resultados: Foram avaliados 32 pacientes no período estudado, com média de idade de 38,68 anos. A relação entre homens e mulheres foi $4: 1$ e as causas mais frequentes foram queda de altura (46,87\%) e acidentes de trânsito (46,87\%). A transição toracolombar foi a mais acometida (40,62\%) com a vértebra de $L 1$ envolvida em 23,8\% das vezes. Apresentaram déficit neurológico 40,62\% dos pacientes. O tempo de permanência hospitalar teve mediana de 14 dias e os pacientes com déficit neurológico permaneceram internados por período mais prolongado ( $p<0,001$ ), com aumento dos custos hospitalares $(p=0,015)$. O custo médio da internação foi de $U \$ 2.874,80$. A presença de $B C P$ aumentou o custo da internação e os pacientes com lesão medular tiveram mais BCP $(p=0,014)$. Conclusão: Políticas públicas com ênfase na redução de acidentes de trânsito e quedas podem ajudar a reduzir a incidência dessas lesões e estudos com foco nos gastos hospitalares e em reabilitação precisam ser realizados no Brasil para determinar o fardo socioeconômico do traumatismo vertebral e traumatismo medular.

Descritores: Coluna vertebral; Fraturas da coluna vertebral; Traumatismos da coluna vertebral.

\section{RESUMEN}

Objetivo: Describir la epidemiología de los pacientes con fractura de columna toracolumbar sometidos a cirugía en el Hospital Cristo Redentor y los costos relacionados. Métodos: Estudio epidemiológico prospectivo entre julio de 2014 y agosto de 2015 de pacientes con fracturas de la columna toracolumbar con indicación de cirugía. Se analizaron las variables sexo, edad, costo de hospitalización, niveles fracturados, niveles de artrodesis, infección del sitio quirúrgico, ITU o BCP, lesión de la médula espinal, etiología, duración de la estancia hospitalaria, tiempo del procedimiento y la escala visual analógica (EVA). Resultados: Fueron evaluados 32 pacientes durante el período de estudio, con un promedio de edad de 38,68 años. La relación entre hombres y mujeres fue de 4:1 y las causas más frecuentes fueron las caídas de altura (46,87\%) y los accidentes de tránsito (46,87\%). La transición toracolumbar fue la más afectada (40,62\%) con la vértebra de L1 involucrada en 23,8\% de los casos. Presentaron déficit neurológico 40,62\% de los pacientes. La estancia hospitalaria tuvo mediana de 14 días y los pacientes con déficit neurológico permanecieron hospitalizados por un período más largo ( $p<0,001)$, con un aumento de los gastos de hospital ( $p=0,015)$. El costo promedios de hospitalización fue de U\$2.874,80. La presencia de BCP aumentó el costo de la hospitalización y los pacientes con lesión de la médula espinal tuvieron más $B C P(p=0,014)$. Conclusión: Políticas públicas, con énfasis en la reducción de los accidentes de tránsito y las caídas pueden ayudar a reducir la incidencia de estas lesiones y los estudios centrados en los costos hospitalarios y de rehabilitación deben ser llevados a cabo en Brasil para determinar la carga socioeconómica del trauma espinal y la lesión de médula espinal.

Descriptores: Columna vertebral; Fracturas de la columna vertebral; Traumatismos vertebrales. 


\section{INTRODUCTION}

Spine and spinal cord trauma (SCT) is defined as any externally caused injury to any spinal segment, with or without involvement of the spinal cord and/or nerve roots. ${ }^{1}$ The worldwide and Brazilian incidences of spinal trauma are around 50 and 40 new cases for every million inhabitants per year, respectively, the latter being similar to that in the United States where the cost is estimated at 300 million dollars annually. ${ }^{1-4}$

It is estimated that in the USA there are between 185.000 and 400.000 people living with spinal cord injuries and around 2000 hospital beds are required each year to treat these patients. ${ }^{5}$ The total incidence in Brazil is not known because of the precariousness of records and because it is not a situation requiring mandatory notification. ${ }^{6}$ There are between 6000 and 8000 new cases of spinal cord injury per year in Brazil, with a 4 to 1 ratio of men to women and $60 \%$ of the men between 10 and 30 years of age. ${ }^{4,6}$ Spinal cord lesions cause personal disabilities, lifestyle changes, and high socioeconomic costs for both the patients and the state., ${ }^{2,7}$

Around 15 to $20 \%$ of patients with spinal trauma have associated neurological damage when evaluated using the ASIA (American Spinal Injury Association) scale score. Considering the disability that spinal cord trauma causes, the costs for these patients becomes a serious public health issue. ${ }^{2,7-9}$

The objective of this study was to evaluate a population with spinal trauma who underwent spine fixation surgery, its epidemiology, and the costs related to their hospitalization.

\section{MATERIALS AND METHODS}

A prospective cohort study was conducted between July, 2014, and August, 2015. The inclusion criteria were presentation of an unstable traumatic spinal injury between the thoracic and sacral segments. Instability criteria were defined using the AOSPINE trauma classification and the TLICS system (Thoracolumbar Injury Classification and Severity Score). ${ }^{10,11}$ The exclusion criteria were oncological patients with pathological fractures due to neoplasia and previous instrumented spine surgery.

The variables analyzed were sex, age, body mass index (BMI), hospitalization costs (converted into US dollars using the exchange rate on the day of discharge), fracture levels, arthrodesis levels, and the presence or absence of infection at the surgical site, urinary tract infection (UTI), or bronchopneumonia (BCP), neurological deficit, etiology of the trauma, total days of hospitalization, days of pre- and postoperative hospitalization, and surgical time. The patients were evaluated for spinal pain using the visual analog scale (VAS), which ranges from 0 (without pain) to 10 (with intense pain).

Blood tests for C-reactive protein (CRP) and erythrocyte sedimentation rate (ESR) were evaluated in the preoperative/post trauma period. The values considered to be normal for these variables were less than 10 for CRP and less than 20 for ESR.

The database was built using Microsoft Excel 2011 version 15.24 and the statistical analysis was performed using SPSS version 16.0. The Mann-Whitney and Spearman-Rho tests were used for asymmetric variables and the student's $t$-test was used for variables with normal distribution.

All patients signed the informed consent form and the study was approved by the Institutional Review Board of the Grupo Hospitalar Conceição (CAAE 21374414.5.0000.5530). The patients were followedup in an outpatient clinic for a period of 3 months to 2 years.

\section{RESULTS}

Thirty-two patients in the period between July, 2014 and August, 2015, victims of spinal trauma with lesions classified as unstable and requiring arthrodesis surgery, were included in the study. The average age was 38.68, with a minimum of 17 and a maximum of 65 years of age and a standard deviation of 14.91. A higher prevalence of males was observed, accounting for $81.25 \%$ of the cases. (Table 1)
Trauma resulting from traffic accidents (automobile, motorcycle, and pedestrian) and falls (from a roof, concrete slabs, ladder, or standing position) had the same frequency (46.87\%). Motorcycle accidents were more frequent than car accidents and being run over and fractures of the thoracic vertebrae were more common in motorcycle accidents, while fractures of the lumbar vertebrae were more common in falls and automobile accidents. The ratio between males and females was 6.57:1 for falls and motorcycle accidents and 1.5:1 for car accidents.

An analysis of the skeletal level of the fractures showed fractures occurring from $\mathrm{T} 4$ to $\mathrm{L} 4$, with $\mathrm{L} 1$ being the vertebra most affected (23.8\% of the fractures), followed by T12 (14.3\% of the fractures). The thoracolumbar transition was affected in $40.62 \%$ of the patients. (Table 2).

The incidence of spinal cord trauma was $40.62 \%$, as measured using the ASIA scale. Mortality in this series was $6.25 \%$ (2 cases) from infections following discharge, which occurred in patients with complete spinal cord lesions (one patient with respiratory sepsis and the other with urinary sepsis).

The average hospitalization costs, obtained from bills, were USD $\$ 2,874.80$, with a minimum of USD $\$ 1,212.74$ and a maximum of USD \$4,681.17.

Table 1. Distribution of patient characteristics.

\begin{tabular}{|c|c|}
\hline Variables & Frequency $(\mathrm{n} / \%)$ \\
\hline Number of cases & $32 / 100 \%$ \\
\hline \multicolumn{2}{|l|}{ Sex } \\
\hline Male & $26 / 81.25 \%$ \\
\hline Female & $6 / 18.75 \%$ \\
\hline Tobacco use & $5 / 15.62 \%$ \\
\hline High blood pressure & $6 / 18.75 \%$ \\
\hline DM & $3 / 9.37 \%$ \\
\hline \multicolumn{2}{|l|}{ Age } \\
\hline $10-19$ & $5 / 15.62 \%$ \\
\hline $20-29$ & $5 / 15.62 \%$ \\
\hline $30-39$ & $7 / 21.87 \%$ \\
\hline $40-49$ & $5 / 15.62 \%$ \\
\hline $50-59$ & $7 / 21.87 \%$ \\
\hline $60-69$ & $3 / 9.37 \%$ \\
\hline \multicolumn{2}{|l|}{ Etiology } \\
\hline Fall from height & $15 / 46.87 \%$ \\
\hline Car accident & $5 / 15.62 \%$ \\
\hline Motorcycle accident & $8 / 25 \%$ \\
\hline Being run over & $2 / 6.25 \%$ \\
\hline Boating accident & $1 / 3.12 \%$ \\
\hline Direct trauma & $1 / 3.12 \%$ \\
\hline \multicolumn{2}{|l|}{ ASIA } \\
\hline A & $11 / 34.37 \%$ \\
\hline $\mathrm{B}$ & 0 \\
\hline $\mathrm{C}$ & $1 / 3.12 \%$ \\
\hline $\mathrm{D}$ & $1 / 3.12 \%$ \\
\hline $\mathrm{E}$ & $19 / 59.37 \%$ \\
\hline \multicolumn{2}{|l|}{ Level of fracture* } \\
\hline Thoracic & $25 / 78.12 \%$ \\
\hline Lumbar & $17 / 53.12 \%$ \\
\hline Thoracolumbar transition (T12-L1) & $13 / 40.62 \%$ \\
\hline Mid-thoracic (T4-T8) & $9 / 28.12 \%$ \\
\hline Infection & $11 / 33.33 \%$ \\
\hline Urinary (UTI) & $6 / 18.8 \%$ \\
\hline Bronchopneumonia (BCP) & $3 / 9.37 \%$ \\
\hline Surgical site infection & $2 / 6.25 \%$ \\
\hline
\end{tabular}

*value may be greater than $100 \%$. 
Table 2. Vertebrae affected

\begin{tabular}{c|c}
\hline Levels & Number of fractures \\
\hline T4 & 3 \\
\hline T5 & 2 \\
\hline T6 & 4 \\
\hline T7 & 2 \\
\hline T8 & 2 \\
\hline T9 & 1 \\
\hline T10 & 2 \\
\hline T11 & 4 \\
\hline T12 & 6 \\
\hline L1 & 10 \\
\hline L2 & 3 \\
\hline L3 & 3 \\
\hline L4 & 1 \\
\hline Total & 32 \\
\hline
\end{tabular}

The average length of the hospitalization was 14 days, with a minimum of 5 and a maximum of 79 days. The correlations between cost and both total and postoperative hospitalization times were statistically significant $(r S=0.39 ; p=0.036$ and $r S=0.49 ; p=0.006$ respectively). There was no significant difference in the cost analysis related to an increase in the period between the trauma and the surgery $(r S=-0.25 ; p=0.895)$.

Urinary tract infections occurred in six patients (18.8\%), bronchopneumonia in $3(9.4 \%)$, and infections of the surgical site in 2 cases. In our sample, $31 \%$ of the cases were obese $(\mathrm{BMI}>30)$.

The number of fused levels has a positive correlation with the cost of hospitalization ( $p<0.001)$. Patients with spinal cord trauma had longer postoperative hospitalization time $(p=0.001)$, with higher hospitalization costs $(p=0.015)$. Patients with spinal cord trauma had more expensive hospitalizations, averaging USD \$677.75 more expensive than those without spinal cord injury, per admission.

Patients with BCP had higher hospitalization costs $(p=0.025)$ and patients with spinal cord trauma had higher rates of bronchopneumonia $(p=0.014)$.

In the preoperative examinations, changes in the ESR were observed in $44.8 \%$ and in CRP in $73.3 \%$ of the patients analyzed (four patients did not have ESR data and 3 patients did not have CRP data). The average surgical time was 150 minutes, with a standard deviation (SD) of 33.36 minutes. The median score on the visual analog scale for spinal pain in the preoperative period was $7 / 10$ for patients with complete neurological deficit and 6/10 for patients without neurological deficit.

\section{DISCUSSION}

Vertebral trauma is a sudden pathology, more often affecting young adults at the peak of their productive years. When associated with spinal cord trauma, it impacts their lives and the lives of their families. Besides the psychosocial impact, it creates a public health problem in light of the loss of years of productivity and treatment and rehabilitation costs. ${ }^{2,7}$

The incidence of vertebral trauma in this series, taking the population admitted to this hospital into account (788.434 patients in 2015 according to data from the hospital and from the IBGE), was 40.58 per million during the period analyzed. The incidence of spinal cord trauma was 16.48 per million, below the worldwide figure of 40 cases per million, 1,6,12 and the incidence in Brazil of 71 cases per million. ${ }^{6}$ The difference in incidence may be related to the lack of notification of this health condition in Brazil ${ }^{6}$ and to the exclusion criteria of this study (disregarding patients with neoplasia). Another fact that should be taken into account is the existence of other hospitals in the metropolitan regions that treat patients with vertebral and spinal cord trauma.

Most of the affected subjects were men (81.25\% of the cases), which is in line with the worldwide profile. . $^{1,6,8,12-15}$ The most common fracture mechanisms were falls (46.87\%) and traffic accidents (46.87\%), as different from the world literature where falls prevail. $8,12,13$ In our series, males predominated all causes, with a male to female ratio of 6.57:1, with a more balanced relationship if we consider car accidents alone, where the ratio was 1.5:1. The increase in cases of vertebral trauma in women can be attributed to their greater inclusion in the labor market and the consequent exposure to the risk of accidents. ${ }^{1,6}$

The most affected vertebral level in our study was $L 1$, in $23.8 \%$ of the cases, with the thoracolumbar transition involved $40.65 \%$ of the time, which is consistent with the literature. , $^{1,6,12-14}$

Spinal cord lesion occurred in $40.62 \%$ of the patients, which is comparable to the study by Tavares et al., ${ }^{14}$ which observed neurological lesions in $48.1 \%$. In general, the literature reports neurological deficit associated with thoracolumbar spine fractures in around $15-20 \%$ of the cases. ${ }^{3,8,16}$ This difference may be attributed to the inclusion criteria in this study, since only patients with vertebral instability and an indication for surgery with more serious injuries and greater potential for causing spinal cord lesions were included.

The median number of hospitalization days was 14 ( \pm 16.6$)$. The longest hospitalization time was 79 days and the shortest was 5 days. In our study, hospitalization time was shorter than that reported in the study by Santos et al., ${ }^{17}$ where they observed an average hospitalization of 38.77 days and 19.15 days in the Rio de Janeiro state and municipal networks, respectively. This difference in hospitalization time might be attributable to regional factors. We had no cases of mortality in patients with SCT during hospitalization, although death occurred in two cases (6.25\%) following discharge, more than 30 days after surgery, from clinical conditions associated with spinal cord trauma (one case of urinary sepsis and one of respiratory sepsis in patients with complete neurological deficit). Prolonged hospitalizations were largely associated with extended postoperative periods, increasing the costs. If the healthcare system had post-SCT neurological rehabilitation facilities, perhaps the specialized hospital costs would be reduced. ${ }^{2}$

The patients with neurological damage in this series had longer hospitalizations than those without neurological damage. This was associated with higher hospital costs and is probably explained by the severity of the patients, complications, rates of infection requiring hospital treatment, and the involvement of specialized teams, including the multidisciplinary team, as already cited by Santos et al. ${ }^{17}$ The average hospital cost was USD $\$ 2,874.80$, higher than that reported by Sayole et al. ${ }^{17}$ at between USD $\$ 164$ and USD \$653 (depending on the dollar exchange rate during the 1996-2011 period, not included by the author). This difference can be explained by the method used in that study, which conducted a retrospective review of the $\mathrm{SIH}-\mathrm{SUS}$ system (Hospital Information System of the Unified Health System) using the clinical treatment code for spine and spinal cord trauma, which does not include the payment for instrumented spine surgery - hospitalization codes with fixed payment values in the unified health system, leaving out the billing data.

All the patients with BCP had complete neurological lesions, involvement at the thoracic level, and 3 or more fusioned levels. They generated the highest costs, which may be related to the complete neurological lesion and the number of fused levels, but not directly to the BCP or its treatment.

The costs reported in this study only address the hospitalization, and do not include rehabilitation costs, days out of work, loss of productivity, or socioeconomic impact to the state or to the family, among others. Brazil lacks studies that evaluate the real situation and records of patients with spinal fractures and spinal cord lesions lack clarity. In an Australian study, the total estimated 2008 costs to treat spinal cord injuries was two billion dollars, with 1.3 billion dollars for tetraplegia and 687.7 million for paraplegia. The productivity costs, not directly linked to the cost of the condition, reached 1.2 billion dollars in Australia that year. These expenditures related to a total of 273 cases. ${ }^{7}$ According to the February 2013 data of the National Spinal 
Cord Injury Center in Birmingham, Alabama, the average direct cost of a neurological injury can reach USD $\$ 508,904$ in the first year and USD $\$ 67,415$ each subsequent year. These amounts do not include lost salaries, benefits, and productivity, which average USD $\$ 70,575$ a year and can vary in accordance with the severity of the injury, the patient's education, and previous work experience in the region. ${ }^{2}$

Infection of the surgical site had occurred in 2 patients in our series (6.25\%) up until that point in the follow-up: one case of acute infection (within 30 days following surgery) and another of chronic infection (between 30 days and 1 year following surgery). This rate is lower than the worldwide literature number, which is from 10 to $20 \%{ }^{18,19}$

Among the limitations of this study we note the exclusion of patients who received conservative treatment for SCT, which is not representative of the real epidemiology of spine and spinal injuries in Porto Alegre. The lack of Brazilian data for loss of productivity costs, government social security costs, and the burden to both society and family does not express the true socioeconomic impact of this problem, and a comparison of Brazilian and foreign data does not reflect Brazilian reality.

\section{CONCLUSION}

Given that traffic accidents and falls are the major causes of spine injuries and neurological damage, more investments in workplace accident prevention, elimination of the risks of falls, traffic infrastructure, and public awareness can reduce the burden that this condition imposes on both patients and government. Studies of hospital expenses for vertebral and spinal cord trauma and of rehabilitation need to be conducted to assess the real costs and the socioeconomic factors of vertebral/spinal cord injuries in Brazil.

The lower incidence of spinal cord lesions in the study can be addressed via a multicenter study in the city of Porto Alegre and the proper storage of data, especially describing spine and spinal cord trauma, vertebral trauma, and spinal cord injury can help to clarify the epidemiology of these distinct, but related, entities.

All the authors declare that there are no potential conflicts of interest regarding this article.

CONTRIBUTIONS OF THE AUTHORS: Each author made significant individual contributions to the development of this manuscript. TLN was the main contributor to the writing of the manuscript. AMLC, FMLC, and ES were the surgeons and instructors. LPWR, MMR, LPA, GF, GFG, and TLN contributed to data collection, interviewing, patient follow-up, literature review, statistical analysis, and formatting of the manuscript. All the authors viewed the final manuscript.

\section{REFERENCES}

1. Brito LMO, Chein MBD, Marinho SC, Duarte TB. Avaliação epidemiológica dos pacientes vítimas de traumatismo raquimedular. Rev Col Bras Cir. 2011;38:304-9.

2. Centro de Estadísticas Nacionales de Lesiones de Médula Espinal (Nacional SCI Statistical Center). Lesión de la médula espinal. Datos y Cifras a la Vista. Birmingham, Alabama; 2012. Disponível em: https://www.nscisc.uab.edu/PublicDocuments/fact_figures_docs/Facts\%202013\%20Spanish.pdf

3. Defino HLA. Trauma raquimedular. Medicina, Ribeirão Preto. 1999:32:388-400.

4. Brasil. Ministério da Saúde. Secretaria de Atenção à Saúde. Departamento de Ações Programáticas Estratégicas. Diretrizes de Atenção à Pessoa com Lesão Medular/Ministério da Saúde, Secretaria de Atenção à Saúde, Departamento de Ações Programáticas Estratégicas e Departamento de Atencão Especializada. Brasília : Ministério da Saúde, 2013.

5. DeVivo MJ, Fine PR, Maetz HM, Stover SL. Prevalence of spinal cord injury: a reestimation employing life table techniques. Arch Neurol. 1980;37(11):707-8.

6. Campo MF, Ribeiro AT, Listik S, Pereira CAB, Andrade Sobrinho J, Rapoport A. Epidemiologia do traumatismo da coluna vertebral. Rev Col Bras Cir. 2008:35(2):88-93.

7. The economic cost of spinal cord injury and traumatic brain injury in Australia. Rep. by Access Econ. Vic. Neurotrauma Initiat. 31 (2009). Disponível em: https://www.tac.vic.gov. au/about-the-tac/our-organisation/research/tac-neurotrauma-research/vni/the20economic20 cost20of20spinal20cord20injury20and20traumatic20brain20injury20in20australia.pdf

8. Fernandes R, Gomes EGF, Gusmão MS, Amorim Junior DC, Simões Marcus TV, et al. Estudo Clinico epidemiologico das fraturas da coluna vertebral. Coluna/Columna. 2013;11(3): 230-3.

9. Ditunno JF Jr, Young W, Donovan WH, Creasey G. The international standards booklet for neurological and functional classification of spinal cord injury. American Spinal Injury Association. Paraplegia 1994:32(2):70-80.

10. Lee JY, Vaccaro AR, Lim MR, Oner FC, Hulbert RJ, Hedlund R, et al. Thoracolumbar injury classification and severity score: a new paradigm for the treatment of thoraco- lumbar spine trauma. J Orthop Sci. 2005:10(6):671-5.

11. Vaccaro AR, Oner C, Kepler CK, Dvorak M, Schnake K, Bellabarba C, et al. AOSpine thoracolumbar spine injury classification system: fracture description, neurological status, and key modifiers. Spine (Phila Pa 1976). 2013:38(23):2028-37.

12. Rodrigues $L C L$, Bortoletto $A$, Matsumoto $M H$. Epidemiologia das fraturas toracolombares cirúrgicas na zona leste de São Paulo. Coluna/Columna. 2010;9(2):132-7.

13. Cunha MLV, Cunha MLV, Veríssimo DCA, Rehder R, Borba LAB. Estudo epidemiológico das fraturas de coluna em centro de referência para patologia espinhal no Paraná. Arq Bras Neurocir. 2012;31(4):179-83

14. Tavares CB, Souza EB, Borges IBC, Freire Neto NG, Godinho Júnior AA. Perfil epidemiológico dos pacientes com fraturas torácicas e lombares tratadas cirurgicamente no Serviço de Neurocirurgia do Hospital de Base do Distrito Federal (Brasília-Brasil). Arq Bras Neurocir. 2013;32(1):19-25

15. Morais DF, Sppotti AR, Cohen MI, Mussi SE, Melo Neto JS,Tognola WA. Perfil epidemiológico de pacientes com traumatismoraquimedular atendidos em hospital terciário. Coluna/Columna. 2013:12(2):149-52

16. Kriek JJ, Govender S. AO-classification of thoracic and lumbar fractures--reproducibility utilizing radiographs and clinical information. Eur Spine J. 2006:15(8):1239-46.

17. Santos TSC Guimarães RM, Boeira SF. Santos C. Epidemiologia do trauma raquimedular em emergências públicas no município do Rio de Janeiro. Esc Anna Nery.2012;16 (4):747-53.

18. O'Neill KR Smith JG, Abtahi AM, Archer KR, Spengler DM, McGirt MJ et al. Reduced surgical site infections in patients undergoing posterior spinal stabilization of traumatic injuries using vancomycin powder. Spine J. 2011;11(7):641-6.

19. Sweet FA, Roh M, Sliva C. Intrawound application of vancomycin for prophylaxis in instrumented thoracolumbar fusions: efficacy, drug levels, and patient outcomes. Spine (Phila Pa 1976). 2011;36(24):2084-8 